\title{
Improvement of organic matter digestibility along with changes of physical properties of rice straw by chemical treatments*
}

\author{
J.K. Wang, J.X. Liu ${ }^{1}$, Y.M. Wu and J.A. Ye \\ College of Animal Science, Zhejiang University \\ 310029, Hangzhou, China
}

(Received 23 March 2005; revised version 3 October 2005; accepted 6 January 2006)

\begin{abstract}
This study was carried out to study the effects of different chemical treatments on physical properties and digestion of rice straw. Rice straw was treated with sodium hydroxide $(\mathrm{NaOH})$ at 15,30 , 45,60 or $75 \mathrm{~g} / \mathrm{kg}$ dry matter, ammonia bicarbonate $\left(\mathrm{NH}_{4} \mathrm{HCO}_{3}\right)$ at $30,60,90,120$ or $150 \mathrm{~g} / \mathrm{kg}$ or their combinations ( 10 or $20 \mathrm{~g} \mathrm{NaOH} / \mathrm{kg}$ and 30,60 or $90 \mathrm{~g} \mathrm{NH}_{4} \mathrm{HCO}_{3} / \mathrm{kg}$ ), respectively. The relationship between straw digestion and its physical properties was analysed. Treatment with $\mathrm{NaOH}$ increased the volumetric weight (VW), swelling capacity (SC), water-holding capacity (WHC), and in vitro organic matter digestibility (OMD), and decreased specific porosity (SP) of rice straw linearly. Treatment with $\mathrm{NH}_{4} \mathrm{HCO}_{3}$ did not significantly affect VW, SC, or SP, but increase OMD linearly and tended decrease WHC. For the combination treatment of $\mathrm{NaOH}$ and $\mathrm{NH}_{4} \mathrm{HCO}_{3}$, there existed significant interactions on $\mathrm{SC}, \mathrm{SP}$ and OMD. A significant linear correlation was found between OMD and VW, SC, SP, or WHC, when the data for all treatments were analysed. The accuracy of regression equation could be improved by including multiple physical property parameters. It is inferred that change in all physical properties is indicative of improvement in straw digestion after treatment.
\end{abstract}

KEY WORDS: rice straw, chemical treatment, physical properties, straw digestion

\section{INTRODUCTION}

In China, annual yield of rice straw totals currently about 188 million tonnes (Guo et al., 2002). Unfortunately, low nutrient content and poor digestibility of rice straw limit its efficient use in the diets for lactating and growing ruminants. Physical,

\footnotetext{
$\bar{*}$ Supported by the National Natural Science Foundation of China, Grant No. 30270943, and TransCentury Training Programme Foundation for the Talents by the Ministry of Education of China

${ }^{1}$ Corresponding author: e-mail: liujx@zju.edu.cn
} 
chemical and biological pretreatments have been widely applied to upgrade the crop residues (Han and Garrett, 1986; Chaudhry, 1998). It has been found that alkali treatment may reduce the lignification of straw (Xiao et al., 2001), cleavage the ester and ether linkages between hemicellulose and lignin (Lawther et al., 1996), decrease the crystallinity of cellulose (Goto and Yokoe, 1996; Isogai and Usuda, 1996), and weaken the interlinkage of the silica-covered cuticle with underling tissues (Bae et al., 1997). These changes may result in modified physical properties of straw, reflected by increased swelling capacity and water retention of straw (Goto and Yokoe, 1996), and hence render the treated straw susceptible to attack by rumen cellulolytic microbes (Xu et al., 1993; Chaudhry, 2000; Selim et al., 2004; Liu et al., 2005).

The physical properties that strongly affect fermentation pattern in human colon are mainly the particle size or bulk volume, the surface area characteristics, and the hydration. For example, particle size influences transit time, fermentation, and faecal excretion (Guillon and Champ, 2000). These physical properties can be expressed by volumetric weight, water-holding capacity, etc. (Goto and Yokoe, 1996; Sangnark and Noomhorm, 2004). Measurement of the parameters for physical properties may quantitatively reveal the mechanism with which to upgrade the crop residues by chemical treatment, and simplify the assessment of treatment efficacy. However there are few systemic studies focused on physical properties and their relationship with nutritive value of cereal straws.

Besides its resourcefulness, ammonia bicarbonate $\left(\mathrm{NH}_{4} \mathrm{HCO}_{3}\right)$ is cheaper and decomposes more easily than urea, which is beneficial for inhibition of mould growth during the initial stage of treatment, especially in the rainy season (Liu et al., 1992). However, one may not expect strong effects on physical properties of straw due to its week alkali effect. Sodium hydroxide $(\mathrm{NaOH})$ had strong alkalinity (Han and Garrett, 1986), so the treatment with combination of $\mathrm{NH}_{4} \mathrm{HCO}_{3}$ plus $\mathrm{NaOH}$ may be expected have an optimal effect.

Therefore, this study was conducted to investigate the effects of $\mathrm{NaOH}$, $\mathrm{NH}_{4} \mathrm{HCO}_{3}$ or their combination treatments on physical parameters of rice straw, such as volumetric weight, swelling capacity, specific porosity and water-holding capacity, and to analyse relationships between physical properties and digestion of straw.

\section{MATERIAL AND METHODS}

\section{Preparation and treatment of rice straw}

The rice straw used was from the late season rice (va. Yiu64, $\mathrm{V}_{35}$ ), cultivated in Zhejiang province. Following the harvest, rice straw was air-dried and manually 
chopped to 3-5 $\mathrm{cm}$ lengths. Chopped straw was put into polyethylene bags in three duplicates, and mixed with different dosages of $\mathrm{NaOH}, \mathrm{NH}_{4} \mathrm{HCO}_{3}$, or their combination, respectively. Dosage of $\mathrm{NaOH}$ was at $15,30,45,60$ and $75 \mathrm{~g} / \mathrm{kg}$ straw dry matter (DM), respectively. Amount of water used to dissolve $\mathrm{NaOH}$ was controlled to adjust the initial moisture content of the treated rice straw to about $40 \%$. After rice straw was thoroughly mixed with $\mathrm{NaOH}$ solution, the sealed bags with straw were left in a thermostated container at $35^{\circ} \mathrm{C}$ for $3 \mathrm{~d}$ (Han and Garret, 1986). Dosage of $\mathrm{NH}_{4} \mathrm{HCO}_{3}$ was at $30,60,90,120$ and $150 \mathrm{~g} / \mathrm{kg} \mathrm{DM}$, respectively, with initial moisture content of the treated straw at about $50 \%$. After rice straw was thoroughly mixed with $\mathrm{NH}_{4} \mathrm{HCO}_{3}$ solution, the materials were left in a thermostated container at $35^{\circ} \mathrm{C}$ for $10 \mathrm{~d}$ (Liu et al., 1992). To evaluate combination treatments, chopped rice straw was treated with 10 or $20 \mathrm{~g} \mathrm{NaOH} / \mathrm{kg}$ $\mathrm{DM}$ at $35^{\circ} \mathrm{C}$ for $3 \mathrm{~d}$, and then with 30,60 or $90 \mathrm{~g} \mathrm{NH}_{4} \mathrm{HCO}_{3} / \mathrm{kg} \mathrm{DM}$ at $35^{\circ} \mathrm{C}$ for $7 \mathrm{~d}$. Untreated rice straw was used as control.

\section{Measurement of chemical compositions}

Untreated and treated rice straw were oven-dried and ground to pass a $1 \mathrm{~mm}$ sieve for chemical analysis. Contents of crude protein $(\mathrm{CP})$ and ash were determined according to AOAC (1990). Neutral detergent fibre (NDF), acid detergent fibre (ADF), and acid detergent lignin (ADL) were determined following the procedures by Van Soest et al. (1991). Total silica content was measured directly starting from the ADF procedure of the sequential analysis and termed as acid-detergent insoluble silica (ADISi) after Van Soest et al. (1991).

\section{Measurement of physical properties}

The milled samples of untreated and treated rice straws were screened with a $0.45 \mathrm{~mm}$ screen, and only the samples on the screen were taken for later analysis to decrease discrepancy (Zhang, 1995; Sangnark and Noomhorm, 2004).

Volumetric weight $(V W)$. Half gram of dry ground samples $(\mathrm{W})$ was put into $10 \mathrm{ml}$-scaled glass tube. The tube was gently rapped to vent air space, and the volume (V) of samples was recorded. The VW was expressed as the dry weight per volume sample $(\mathrm{g} / \mathrm{ml})$.

Swelling capacity $(S C)$. Eight $\mathrm{ml}$ of $0.9 \% \mathrm{NaCl}\left(\mathrm{V}_{0}\right)$ was added to a scaled glass tube containing 0.5 gram of dry samples $(\mathrm{W})$ inside. The volume $\left(\mathrm{V}_{\mathrm{m}}\right)$ of the mixture was recorded after it was stood for $24 \mathrm{~h}$ and the air bubbles were vented. The $\mathrm{SC}$ was calculated using the equation: $\mathrm{SC}(\mathrm{ml} / \mathrm{g})=\left(\mathrm{V}_{\mathrm{m}}-\mathrm{V}_{0}\right) / \mathrm{W}$.

Specific porosity $(\mathrm{SP})$. The SP was calculated from the VW and $\mathrm{SC}$, using the following equation: $\mathrm{SP}(\mathrm{ml} / \mathrm{g})=\left(\mathrm{V}-\left(\mathrm{V}_{\mathrm{m}}-\mathrm{V}_{0}\right)\right) / \mathrm{W}$. 
Water-holding capacity (WHC). The dry samples $(1.5 \mathrm{~g})$ were weighed into a nylon bag ( $40 \mu \mathrm{m}$ mesh, $7 \times 12 \mathrm{~cm}$ inner size). After being soaked in $0.9 \% \mathrm{NaCl}$ at $37^{\circ} \mathrm{C}$ for $2 \mathrm{~h}$, the bags with samples were centrifugated in a dehydrator at $5000 \mathrm{r} / \mathrm{min}$ for $15 \mathrm{~min}$. The weights before $\left(\mathrm{W}_{\text {wet }}, \mathrm{g}\right)$ and after drying $\left(\mathrm{W}_{\text {dried }}, \mathrm{g}\right)$ at $105^{\circ} \mathrm{C}$ for $4 \mathrm{~h}$ were recorded. Weights of the empty nylon bag before $\left(\mathrm{W}_{\text {wet bag }}, \mathrm{g}\right)$ and after drying $\left(\mathrm{W}_{\text {dried bag }} \mathrm{g}\right)$ were obtained in the same way. The WHC was calculated as below:

$$
\mathrm{WHC}(\mathrm{g} / \mathrm{g} \mathrm{DM})=\left(\left(\mathrm{W}_{\text {wet }}-\mathrm{W}_{\text {wet-bag }}\right)-\left(\mathrm{W}_{\text {dried }}-\mathrm{W}_{\text {dried-bag }}\right)\right) /\left(\mathrm{W}_{\text {dried }}-\mathrm{W}_{\text {dried-bag }}\right)
$$

Estimation of in vitro organic matter digestibility (OMD)

The OMD was estimated from the in vitro gas production and crude protein content, which was measured and calculated according to Menke and Steingass (1988). The details for gas test were described elsewhere (Liu et al., 2001).

\section{Statistical analysis}

Data for treatment with $\mathrm{NaOH}$ or $\mathrm{NH}_{4} \mathrm{HCO}_{3}$ alone were analysed by one-way analysis of variance, and the results for combination treatment were analysed by two-way analysis of variance, respectively (SAS, 1996). The dosage of chemical was the source of variation in $\mathrm{NaOH}$ or $\mathrm{NH}_{4} \mathrm{HCO}_{3}$ treatment, and orthogonal polynomial contrasts were used to test for linear, quadratic, cubic, and quartic effects of dosage level. Orthogonal polynomial contrasts were also used to test for linear, quadratic effects of $\mathrm{NH}_{4} \mathrm{HCO}_{3}$ level in combination treatment. The interrelations between physical property parameters and OMD for all treatments were analysed using regression procedure (REG).

\section{RESULTS AND DISCUSSION}

Change in chemical compositions of rice straw by different treatments

Changes in chemical compositions of rice straw by $\mathrm{NaOH}, \mathrm{NH}_{4} \mathrm{HCO}_{3}$, and their combination treatment are presented in Tables 1,2 and 3, respectively. Contents of NDF, ADF, ADL and ADISi were decreased $(\mathrm{P}<0.05)$, and ash was increased linearly $(\mathrm{P}<0.01)$ with increasing $\mathrm{NaOH}$ dosage. Dissimilar with $\mathrm{NaOH}$ treatment, ash was not changed $(\mathrm{P}>0.05)$, and $\mathrm{CP}$ was increased linearly $(\mathrm{P}<0.01)$ with increasing dosage of $\mathrm{NH}_{4} \mathrm{HCO}_{3}$. The effects of $\mathrm{NaOH}$ on NDF, ADL, $\mathrm{CP}$, and ash, and of $\mathrm{NH}_{4} \mathrm{HCO}_{3}$ on $\mathrm{CP}$ were significant $(\mathrm{P}<0.01)$ in combination treatment, and that interaction existed between $\mathrm{NaOH}$ and $\mathrm{NH}_{4} \mathrm{HCO}_{3}$ on $\mathrm{CP}(\mathrm{P}<0.01)$. The change in chemical properties of rice straw by different treatments in this study is consistent with other studies (Chaudhry and Miller, 1996; Shen et al., 1998). 
WANG J.K. ET AL.

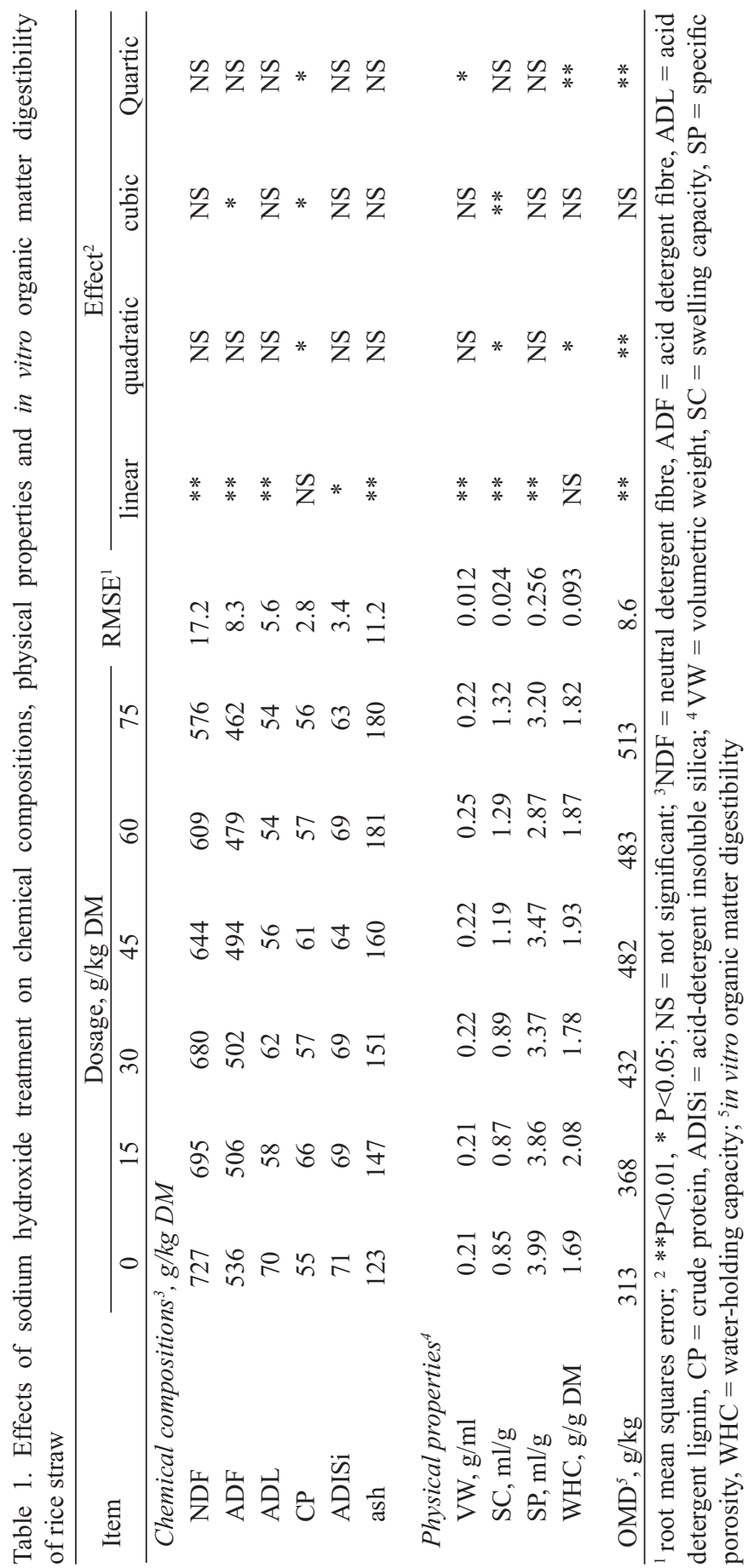




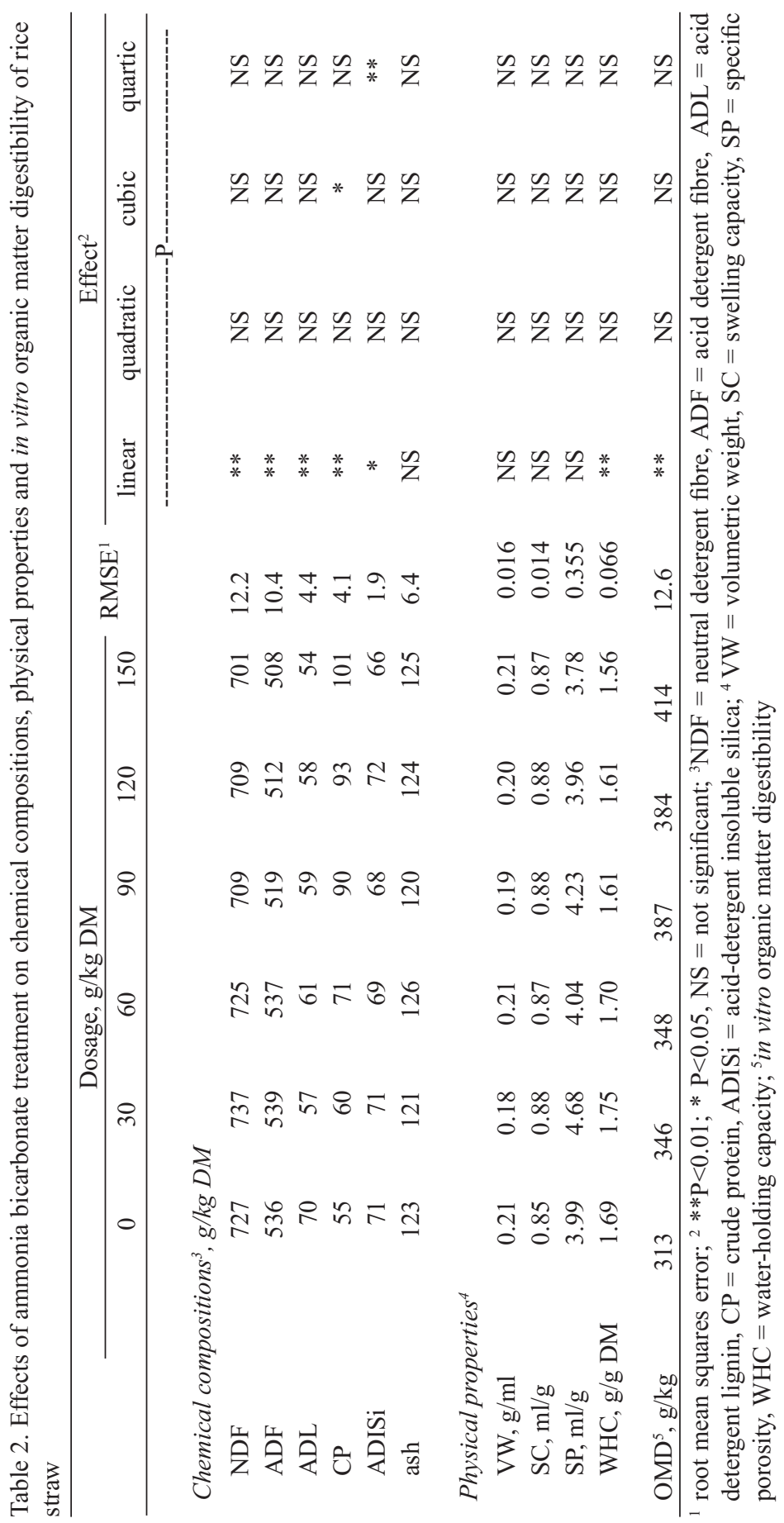




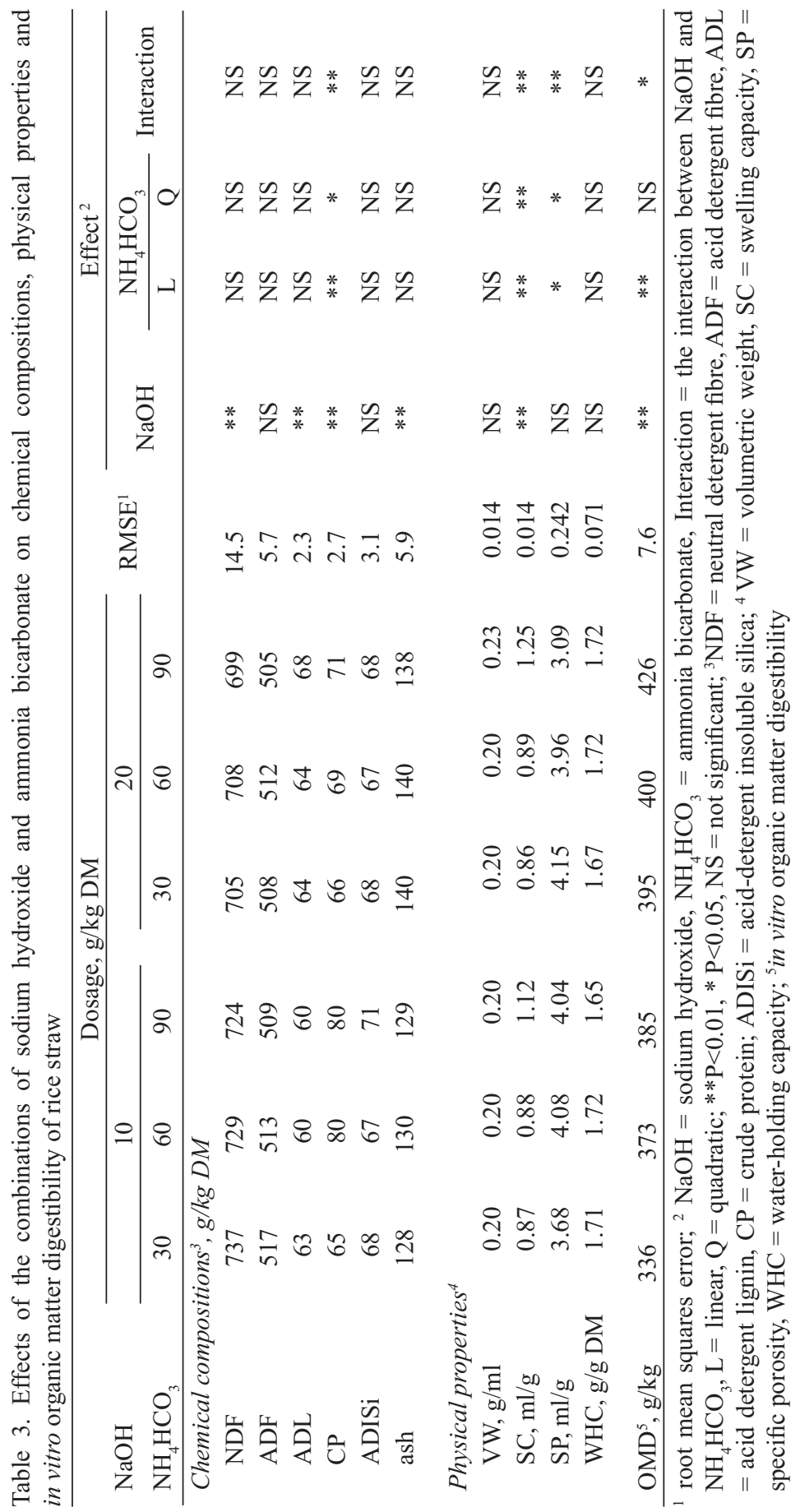


Change in physical properties and digestion of rice straw by different treatments

The analysis of orthogonal polynomial showed that $\mathrm{NaOH}$ treatment increased the VW $(\mathrm{P}<0.01)$, and decreased SP $(\mathrm{P}<0.01)$ of rice straw linearly (Table 1). Treatment with $\mathrm{NH}_{4} \mathrm{HCO}_{3}$ did not significantly affect $\mathrm{VW}$, and $\mathrm{SP}(\mathrm{P}>0.05$; Table 2). The SP was decreased with increasing $\mathrm{NH}_{4} \mathrm{HCO}_{3}(\mathrm{P}<0.05)$ in the combination treatment, while the interaction between $\mathrm{NaOH}$ and $\mathrm{NH}_{4} \mathrm{HCO}_{3}$ affected this change $(\mathrm{P}<0.01$; Table 3$)$. The effect of $\mathrm{NaOH}, \mathrm{NH}_{4} \mathrm{HCO}_{3}$ or the interaction between them on the VW was not significant $(\mathrm{P}>0.05$; Table 3$)$.

The VW is the weight of material per unit volume, and the SP is indicative of the ratio of the lacuna volume out of cell wall substantiality to the total weight of straw. The change observed in VW or SP may reflect the modification of material structure. The increased VW or decreased SP indicates material contracted, while a decreased VW or increased SP value reflects material expanded (Zhang, 1995). In this study, the significant negative correlation between VW and SP (-0.932) was observed (Table 4). Increase of the $\mathrm{VW}$ in $\mathrm{NaOH}$-treated straw may be caused by the high permeation of sodium ion. Although it was reported that liquid ammonia had the ability to form an ammonia-cellulose complex and to decrease the crystallinity of cellulose (Isogai and Usuda, 1992), Goto and Yokoe (1996) observed that gaseous ammonia-treated barley straw had $14 \%$ lower ratio of crystalline to amorphous regions than did the untreated straw. Lack of effect of $\mathrm{NH}_{4} \mathrm{HCO}_{3}$ on VW or SP suggests the weakness of ammonia released from $\mathrm{NH}_{4} \mathrm{HCO}_{3}$ on straw structure.

Table 4. Correlation coefficients between physical property parameters and in vitro organic matter digestibility of rice straw ${ }^{1}$

\begin{tabular}{cccccc}
\hline Correlation & VW & SC & SP & WHC & OMD \\
\hline VW & 1.000 & $0.696^{* *}$ & $-0.932^{* *}$ & $0.476^{* *}$ & $0.614^{* *}$ \\
SC & & 1.000 & $-0.752^{* *}$ & $0.412^{* *}$ & $0.789^{* *}$ \\
SP & & 1.000 & $-0.420^{* *}$ & $-0.702^{* *}$ \\
WHC & & & 1.000 & $0.364^{* *}$ \\
OMD & & & & 1.000 \\
\hline
\end{tabular}

${ }^{1} \mathrm{VW}=$ volumetric weight, $\mathrm{SC}=$ swelling capacity, $\mathrm{SP}=$ specific porosity, $\mathrm{WHC}=$ water-holding capacity, $\mathrm{OMD}=$ in vitro organic matter digestibility, ${ }^{* *} \mathrm{P}<0.01$

The SC of rice straw was increased linearly $(\mathrm{P}<0.01)$ with increasing $\mathrm{NaOH}$ dosage (Table 1), but it was not significantly affected by $\mathrm{NH}_{4} \mathrm{HCO}_{3}$ treatment $(\mathrm{P}>0.05$; Table 2). In the combination treatment, the $\mathrm{SC}$ was increased with increasing $\mathrm{NaOH}$ or $\mathrm{NH}_{4} \mathrm{HCO}_{3}(\mathrm{P}<0.01)$, while the interaction existed between $\mathrm{NaOH}$ and $\mathrm{NH}_{4} \mathrm{HCO}_{3}(\mathrm{P}<0.01$; Table 3$)$. Treatment with $\mathrm{NaOH}$, an alkali agent, may have increased SC by reducing the lignification of straw, and/or by destruction 
of the covalent bond between hemicellulose and cellulose (Spencer and Akin, 1980), and/or weakening of the interlinkage of the silica-covered cuticle with underling tissues (Bae et al., 1997).

The WHC was changed quadratically $(\mathrm{P}<0.05)$ with the dosage of $\mathrm{NaOH}$ (Table 1$)$, a maximum value being estimated to be at the $39 \mathrm{~g} \mathrm{NaOH} / \mathrm{kg}$ DM treatment. However, it was decreased linearly $(\mathrm{P}<0.01)$ with increasing $\mathrm{NH}_{4} \mathrm{HCO}_{3}$ (Table 2$)$ Alkali treatment opens the fibre structure, making available free hydroxyl groups of cellulose to bind with water. Therefore the WHC appears more likely to reflect the degree to which ester cross-linking between cell wall polymers is disrupted by treatment allowing the wall as a whole, rather than just the cellulose microfibrils to swell (Goto and Yokoe, 1996). The quadratic change in the WHC with $\mathrm{NaOH}$ may be dependent on the effect of $\mathrm{NaOH}$ on the ester or ether linkage. The WHC of $\mathrm{NH}_{4} \mathrm{HCO}_{3}$-treated straw obtained in this study was not consistent with results by Goto and Yoke (1996), who showed an increased effect of gaseous ammonia on the WHC of barley straw. This inconsistency may be due to the strict particle size used in this study, and also to the exclusion of leaf blade and leaf sheath materials from the straw samples in their study.

The in vitro OMD was increased linearly $(\mathrm{P}<0.01)$ with $\mathrm{NaOH}$ or $\mathrm{NH}_{4} \mathrm{HCO}_{3}$, either in the single treatment (Tables 1 and 2) or in their combination treatment (Table 3). The increased OMD in pretreated rice straw with $\mathrm{NaOH}$ or $\mathrm{NH}_{4} \mathrm{HCO}_{3}$ are compared with others (Liu et al., 2002).

\section{Correlation between in vitro $O M D$ and physical properties of rice straw}

Correlation coefficients between in vitro OMD and physical property parameters of straw are presented in Table 4 . There was a significant correlation between the OMD and VW ( $\mathrm{r}=0.614), \mathrm{SC}(\mathrm{r}=0.789)$, SP $(\mathrm{r}=-0.702)$, or WHC $(\mathrm{r}=0.364)$. The accuracy could be improved by including multiple physical property parameters in the equation (Table 5), as indicated by the decreased residual standard derivation. The VW, SP, and WHC or SC reflects particle size, surface area characteristic, and

Table 5. Relationship between in vitro organic matter digestibility and physical properties parameters of rice straw

\begin{tabular}{lccc}
\hline Equation $^{1}$ & $\mathrm{R}^{2}$ & $\mathrm{~S}_{\mathrm{y}, \mathrm{x}}{ }^{2}$ & $\mathrm{P}$ \\
\hline $\mathrm{OMD}=123.4+275.6 \mathrm{SC}$ & 0.623 & 28.5 & 0.0001 \\
$\mathrm{OMD}=314.9+209.9 \mathrm{SC}-33.6 \mathrm{SP}$ & 0.650 & 28.0 & 0.0001 \\
$\mathrm{OMD}=688.5+208.8 \mathrm{SC}-69.8 \mathrm{SP}-1123.8 \mathrm{VW}$ & 0.661 & 27.8 & 0.0001 \\
$\mathrm{OMD}=682.9+205.0 \mathrm{SC}-72.1 \mathrm{SP}-1243.0 \mathrm{VW}+24.7 \mathrm{WHC}$ & 0.662 & 27.8 & 0.0001 \\
\hline
\end{tabular}

${ }^{1} \mathrm{OMD}=$ in vitro organic matter digestibility, $\mathrm{g} / \mathrm{kg}: \mathrm{SC}=$ swelling capacity, $\mathrm{ml} / \mathrm{g}: \mathrm{SP}=$ specific porosity, $\mathrm{ml} / \mathrm{g}: \mathrm{VW}=$ volumetric weight, $\mathrm{g} / \mathrm{ml}: \mathrm{WHC}=$ water-holding capacity, g/g DM; ${ }^{2}$ The residual standard deviation, $\mathrm{g} / \mathrm{kg}$ 
fibre hydration of straw, respectively (Guillon and Champ, 2000; Sangnark and Noomhorm, 2004). Relationship between OMD and these parameters indicates that physical properties are closely related to digestion of straw and may be used to evaluate treatment efficiency.

A close correlation also existed among VW, SP, WHC and SC of straw (Table 4). The increased VW was associated with a decreased SP and increased WHC or SC. The straw with decreased particle size, increased surface area and enhanced fiber hydration may be easily penetrated by the rumen fluid and attached by the rumen microbes (Xu et al., 1993; Goto and Yokoe, 1996; Selim et al., 2002), and hence improved digestion may be expected for the treated straw.

\section{CONCLUSIONS}

Treatment of rice straw with $\mathrm{NaOH}$ increases volumetric weight, swelling capacity and water-holding capacity, and decreases the specific porosity. Effects of $\mathrm{NH}_{4} \mathrm{HCO}_{3}$ treatment on physical properties of rice straw are inferior to those with $\mathrm{NaOH}$ treatment. Significant correlation exists between in vitro organic matter digestibility and physical property parameters. It is concluded that change of physical properties is indicative of improvement in straw digestion after chemical treatments.

\section{REFERENCES}

AOAC, 1990. Official Methods of Analysis, Association of Official Analytical Chemists. $15^{\text {th }}$ Edition. Washington, DC

Bae H.D., McAllister T.A., Kokko E.G., Leggett F.L., Yanke L.J., Jakober K.D., Ha J.K., Shin H.T., Cheng K.J., 1997. Effect of silica on the colonization of rice straw by ruminal bacteria. Anim. Feed Sci. Tech. 65, 165-181

Chaudhry A.S., 1998. In vitro and in sacco digestibility of wheat straw treated with calcium oxide and sodium hydroxide alone or with hydrogen peroxide. Anim. Feed Sci. Tech. 74, 301-313

Chaudhry A.S., 2000. Microscopic studies of structure and ruminal fungal colonization in sheep of wheat straw treated with different alkalis. Anaerobe 6, 155-161

Chaudhry A.S., Miller E.L., 1996. The effect of sodium hydroxide and alkaline hydrogen peroxide on chemical composition of wheat straw and voluntary intake, growth and digesta kinetics in store lambs. Anim. Feed Sci. Tech. 60, 69-86

Goto M., Yokoe Y., 1996. Ammoniation of barley straw. Effect on cellulose crystallinity and waterholding capacity. Anim. Feed Sci. Tech. 58, 239-247

Guillon F., Champ M., 2000. Structural and physical properties of dietary fibres, and consequences of processing on human physiology. Food Res. Int. 33, 233-245

Guo T.S., Sanchez M.D., Guo P.Y. (Editors), 2002. Animal Production Based on Crop ResiduesChinese Experiences. FAO Animal Production and Health, FAO, Rome, Paper No. 149, pp. $1-20$ 
Han I.K., Garrett W.N., 1986. Improving the dry matter digestibility and voluntary intake of low quality roughages by various treatments: a review. Korean J. Anim. Sci. 28, 199-236

Isogai A., Usuda M., 1992. X-ray diffraction and solid-state 13C-NMR analyses of celluloses treated with ammonia. Mokuzai Gakkaishi 38, 562-569

Lawther J.M., Sun R., Banks W.B., 1996. Fractional characterization of alkali-labile lignin and alkali-insoluble lignin from wheat straw. Ind. Crops Products 5, 291-300

Liu D., Liu J.X., Zhu S.L., Chen X.J., Wu Y.M., 2005. Histology of tissues and cell wall of rice straw influenced by treatment with different chemicals and rumen degradation. J. Anim. Feed Sci. 14, 373-387

Liu J.X., Dai X.M., Xu N.Y., Wu Y.M., 1992. Ammonia bicarbonate as a source of ammonia for improving the nutritive value of rice straw. In: Recent Advance in Animal Production. Proceeding of the $6^{\text {th }}$ EAAP Animal Science Congress at Bangkok (Thailand), Vol. 3, p. 66

Liu J.X., Susenbeth A., Südekum K.H., 2002. In vitro gas production measurements to evaluate interactions between untreated and chemically treated rice straws, grass hay, and mulberry leaves. J. Anim. Sci. 80, 517-524

Liu J.X., Yao J., Yan B., Yu J.Q., Shi Z.Q., 2001. Effects of mulberry leaves to replace rapeseed meal on performance of sheep feeding on ammoniated rice straw diet. Small Ruminant Res. 39, $131-136$

Menke K.H., Steingass H., 1988. Estimation of the energetic feed value obtained from chemical analysis and in vitro gas production using rumen fluid. Anim. Res. Dev. 28, 7-55

Sangnark A., Noomhorm A., 2004. Chemical, physical and baking properties of dietary fiber prepared from rice straw. Food Res. Int. 37, 66-74

SAS Package, 1996. SAS/STAT User's Guide, version 6.12. Cary, NC, SAS Institute Inc.

Selim A.S.M., Pan J., Suzuki T., Ueda K., Kobayashi Y., Tanaka K., 2002. Postprandial changes in particle associated ruminal bacteria in sheep fed ammoniated rice straw. Anim.Feed Sci. Tech. $102,207-215$

Selim A.S.M., Pan J., Takano T., Suzuki T., Koike S., Kobayashi Y., Tanaka K., 2004. Effect of ammonia treatment on physical strength of rice straw, distribution of straw particles and particleassociated bacteria in sheep rumen. Anim. Feed Sci. Tech. 115, 117-128

Shen H.S., Ni D.B., Sundstøl F., 1998. Studies on untreated and urea-treated rice straw from three cultivation seasons: 1 . Physical and chemical measurements in straw and straw fractions. Anim. Feed Sci. Tech. 73, 243-261

Spencer R.R., Akin D.E., 1980. Rumen microbial degradation of potassium hydroxide-treated coastal bermudagrass leaf blades examined by electron microscopy. J. Anim. Sci. 51, 1189-1196

Van Soest P.J., Robertson J.B., Lewis B.A., 1991. Method for dietary fiber, neutral detergent fiber, and nonstarch polysaccharides in relation to animal nutrition. J. Dairy Sci. 74, 3583-3597

Xiao B., Sun X.F., Sun R.C., 2001. Chemical, structural, and thermal characterizations of alkalisoluble lignins and hemicelluloses, and cellulose from maize stems, rye straw, and rice straw. Polym. Degrad. Stabil. 74, 307-319

Xu N.Y, Liu J.X., Wu Y.M., 1993. Investigation on ammonia bicarbonate treated rice straw by scanning electron microscopy. In: Proceeding of International Conference on Increasing Livestock Production through Utilization of Local Resources. T.S. Guo (Editor). Industrial and Commercial Publishing House, Beijing, pp. 412-419

Zhang F.L., 1995. A study on physico-chemical and nutritional characterization of cereal straws treated by engineering methods (in Chinese). PhD. Thesis, China Agriculture University, pp. 73-78 